\title{
EKSPLORASI VISUALISASI SPASIO-TEMPORAL MENGGUNAKAN PERANGKAT LUNAK QUANTUM GIS DAN PLUGINTIME MANAGER
}

\author{
Totok Wahyu Wibowo \\ email: totok.wahyu@ugm.ac.id \\ Fakultas Geografi, Universitas Gadjah Mada \\ Bulaksumur, Yogyakarta 55281Telp (0274) 6492340
}

\begin{abstract}
Abstrak
Peta sangat dibutuhkan ketika seseorang ingin memahami pola dan hubungan geospasial, tetapi kebanyakan peta membatasi hanya kepada satu satuan waktu tertentu. Beberapa studi tentang kejadian atau proses geografis akan sulit dilaksanakanjika mengabaikan aspek waktu, karena banyak tantangan penting yang dihadapi manusia saat ini, seperti perubahan iklim global, perkembangan ekonomi, dan kesehatan membutuhkan deteksi, analisis perubahan dan tren untuk membantu pemecahan masalah. Visualisasi informasi secara spasio-temporal dimungkinkan dengan menambahkan kemampuan animasi pada peta.Perangkat lunak Quantum GIS (QGIS) merupakan salah satu pilihan dalam pengolahan data geospasial dan memiliki kemampuan untuk menyajikan peta dalam animasi. Kemampuan tersebut tidak lain karena adanya plugin TimeManager, yang dapat ditambahkan oleh pengguna. Tulisan ini akan melakukan eksplorasi kemampuan plugin tersebut untuk menyajikan peta animasi melalui variasi pada step size dan speed. Selain kedua hal tersebut akan dilakukan eksplorasi penyusunan peta animasi dengan efek offset dan penambahan layer data.
\end{abstract}

Kata Kunci:Peta Animasi, Spasio-temporal, QGIS, Time Manager.

\section{Pendahuluan}

Perubahan merupakan salah satu hal yang menarik untuk dikaji baik secara keruangan (spatial) maupun tidak (aspatial).Berdasarkan perubahan yang terjadi dapat dirunut faktor-faktor penyebab perubahan atau seberapa besar perubahan yang terjadi.Jika ternyata dampak perubahan tersebut negatif, dapat dilakukan beberapa strategi untuk mengurangi dampaknya.Perubahan sendiri terikat dengan waktu, yang dalam hal ini terdapat perubahan yang bersifat cepat dan ada pula perubahan yang sifatnya lambat.Dimensi waktu juga merupakan salah satu komponen penyusun data geospasial di samping dimensi lokasi dan dimensi atribut [1]. Dengan demikian peta dapat digunakan untuk mempelajari proses karena dapat memberikan presentasi dan pemahaman yang lebih baik, terutama untuk perubahan terkait fenomena geografis.

Penyajian informasi perubahan dapat dilakukan dengan menggunakan data geospasial untuk memudahkan pemahaman pembaca. Perspektif ruang yang disajikan oleh data geospasial akan membantu pengguna dalam mengaitkannya dengan dunia nyata. Penyajian fenomena dinamis spatio-temporal sebenarnya telah lama dipraktikkan oleh kartograf melalui peta dua dimensional[2].Pada awal tahun 1930-an, kartograf juga bereksperimen dengan menambahkan dimensi waktu untuk merepresen-tasikan proses geografi dinamis dengan tampilan peta animasi [3].

Perkembangan teknologi semakin memudah-kan kartograf untuk menggunakan media animasi dalam pembuatan peta.Salah satu keunggulan menggunakan media animasi ialah pengguna tidak hanya menerapkan skema pengetahuan spasial namun juga skema temporal untuk menginterpretasikan kandungan informasi[4]. Meskipun demikian penyusunan peta animasi merupakan tantangan bagi kartograf yang umumnya terbiasa dengan penyusunan peta statis [5]. Tidak seperti peta statis yang tidak berubah, masing-masing frame dari peta animasi akan tertampil di layar secara singkat, sehinggapengguna peta hanya memiliki sedikit waktu untuk melihat peta secara rinci. Kunci penyusunan peta animasi yang baik ialah penyusunan pilihan interaksi yang sesuai bagi pembaca peta [5]. 
Dalam kurun waktu 15 tahun terakhir telah terjadi perkembangan yang pesat dalam hal (i) perangkat lunak untuk penyusunan peta animasi, (ii) komputer yang semakin murah, (iii) koneksi internet yang semakin kuat dan luas, dan (iv) banyaknya data spasio-temporal yang tersedia dan bersifat open access [3]. Keempat faktor tersebut semakin mempermudah penyusunan peta animasi.Dalam hal perangkat lunak pun, kini terdapat beragam pilihan dan bahkan ada pula yang bersifat open source, salah satunya ialah Quantum GIS (QGIS).

QGIS merupakan perangkat lunak Sistem Informasi Geografis (SIG) open source yang dilisensikan di bawah $G N U$ General Public License. Saat ini QGIS merupakan proyek resmi dari Open Source Geospatial Foundation (OSGeo). Salah satu keunggulan QGIS ialah dapat dipasang (install) pada berbagai sistem operasi komputer, misalnya Linux, Unix, Mac OSX, Windows, hingga Android, serta mendukung berbagai macam format data vektor, raster, dan basisdata. Dalam pengembangannya, QGIS mengandalkan sukarelawan dalam bentuk kontribusi pengkodean, perbaikan cacat program (bug), pelaporan cacat program, dokumentasi, advokasi, dan dukungan terhadap pengguna.

Perkembangan QGIS memang berjalan lambat pada awalnya, hingga selama kurang lebih 7 tahun baru tercipta versi 1.0 dengan nama kode Kore. tiga tahun kemudian, melalui versi 1.8 (Lisboa), QGIS mengalami peningkatan popularitas yang cukup signifikan, oleh karena adanya peningkatan pada antarmuka pengguna yang semakin ramah pengguna (user friendly). Kini pengembangan QGIS dibagi menjadi 2 bagian, yaitu versi Long Term Release (LTR) yang akan mendapatkan dukungan dari pengembang dan versi terbaru yang akan memiliki kemampuan paling mutakhir.

Kemampuan QGIS akan bertambah dengan adanya plugin yang dapat dipasang oleh pengguna sesuai kebutuhannya. TimeManagerialahplugin yang memiliki kemampuan untuk menambahkan kontrol waktu terhadap data geospasial [6]. Pengguna dapat menghasilkan rangkaian gambar berdasarkan pengaturan kecepatan (speed) dan ukuran langkah (step size), lalu menyimpan hasil akhir dalam format video.Semua keunggulan tersebut tersedia dengan kemudahan operasional penggunaannya.

Peluang penggunaan plug-in TimeManagerdalam penyajian peta animasi memang memudahkan pengguna, terutama bagi pengguna yang ingin menyajikan animasi sederhana. Dengan beberapa keterbatasan yang ada, perlu dilakukan eksplorasi kemampuan plugin TimeManageruntuk menyajikan data geospasial secara spasio-temporal.

\section{Metode Penelitian}

a. Data

Data kejadian gempabumi yang diperoleh dari United States Geological Survey (USGS) digunakan sebagai bahan penelitian. Perolehan data dilakukan melalui portal pencarian data gempabumi USGS.Data gempabumi di Indonesia dari tahun 2015-2018 yang memiliki magnitudo lebih dari 5 dipilih agar kuantitas data yang tidak terlalu banyak.Dengan menggunakan kriteria tersebut, terdapat 767 kejadian gempabumi yang tersimpan dalam server USGS.

Data yang diunduh dari server USGS kemudian disimpan dalam tabel dengan format comma separated value (CSV) yang di dalamnya terdapat 22 atribut (kolom). Untuk dapat menyajikan animasi spasiotemporal, minimal dibutuhkan kolom waktu (time), bujur (longitude) dan lintang (latitude). Informasi lain seperti magnitudo dan kedalaman dapat pula disajikan sebagai informasi tematik.

Tabel data gempabumi dalam format CSV kemudian dikonversi menjadi data shapefile (SHP) dengan menggunakan fasilitas yang terdapat dalam QGIS. Pada awalnya data tabel dipanggil dengan menggunakan fasilitas Add delimited text layer dengan mengatur definisi geometri pada titik koordinat. Data sementara yang tertampil kemudian diekspor menjadi format shapefiledengan dimensi titik.

Persebaran data gempabumi yang dapat dilihat pada Gambar 1.1, menunjukkan lebih banyak kejadian gempabumi di wilayah timur Indonesia.Secara lebih rinci terdapat 
pengelompokan pula di utara Provinsi Sulawesi Utara dan di sebelah selatan Provinsi Maluku.Lokasi tersebut merupakan pertemuan antara empat lempeng tektonik, yaitu Eurasia, Pasifik, Australia, dan Filipina [7]. Seperti diketahui aktivitas gempabumi tektonik akan terjadi di daerah pertemuan antar lempeng.

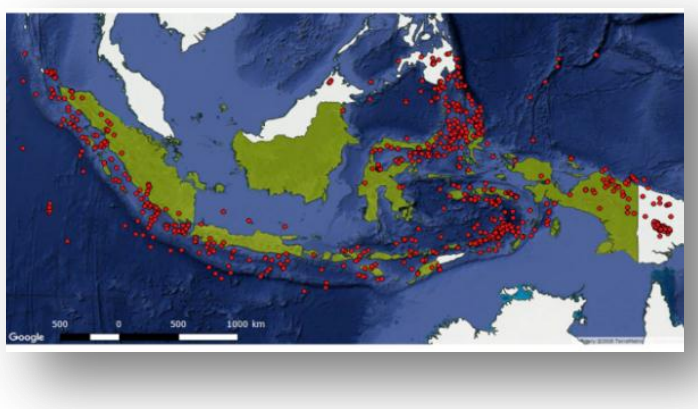

Gambar 1 Persebaran data gempabumi

\section{b. Plugin Time Manager}

Tujuan utama dari Plugin Time Manageradalahuntuk menyediakan penjelajahan data geospasial yang nyaman melalui aspek temporal. Plugin ini memiliki dependensi Python 2.7 dan tersimpan di repositori plugin resmi QGIS, sehingga memudahkan pengguna untuk memasangnya.Sebagai sarana pengaturan, terdapat dock widgetyang menyediakan tombol penggeser waktu dan dialog konfigurasi data (settings).Tampilan awal dock widget tersebut dapat dilihat pada Gambar 2.

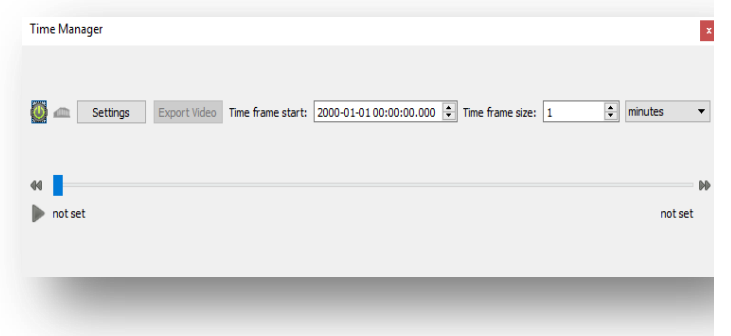

Gambar 2.Dock widget plugin Time Manager

Time Managerhanya mendukung data geospasial yang memiliki timestamp atau penanda waktu di dalam atributnya. Format timestamp yang dapat diterima oleh Time Managersangat beragam dengan berbagai pilihan durasi dan satuan waktu terkecil. Hal ini semakin memudahkan pengguna untuk memanfaatkannya. Berikut ini ialah format timestamp tersebut:
1) $\% \mathrm{Y}-\% \mathrm{~m}-\% \mathrm{~d} \% \mathrm{H}: \% \mathrm{M}: \% \mathrm{~S} . \% \mathrm{f}$
2) $\% \mathrm{Y}-\% \mathrm{~m}-\% \mathrm{~d} \% \mathrm{H}: \% \mathrm{M}: \% \mathrm{~S}$
3) $\% \mathrm{Y}-\% \mathrm{~m}-\% \mathrm{~d} \% \mathrm{H}: \% \mathrm{M}$
4) $\% \mathrm{Y}-\% \mathrm{~m}-\% \mathrm{dT} \% \mathrm{H}: \% \mathrm{M}: \% \mathrm{~S}$
5) $\% \mathrm{Y}-\% \mathrm{~m}-\% \mathrm{dT} \% \mathrm{H}: \% \mathrm{M}: \% \mathrm{SZ}$
6) $\% \mathrm{Y}-\% \mathrm{~m}-\% \mathrm{dT} \% \mathrm{H}: \% \mathrm{M}$
7) $\% \mathrm{Y}-\% \mathrm{~m}-\% \mathrm{dT} \% \mathrm{H}: \% \mathrm{MZ}$
8) $\% \mathrm{Y}-\% \mathrm{~m}-\% \mathrm{~d}$
9) $\% \mathrm{Y} / \% \mathrm{~m} / \% \mathrm{~d} \% \mathrm{H}: \% \mathrm{M}: \% \mathrm{~S} . \% \mathrm{f}$
10) $\% \mathrm{Y} / \% \mathrm{~m} / \% \mathrm{~d} \% \mathrm{H}: \% \mathrm{M}: \% \mathrm{~S}$
11) $\% \mathrm{Y} / \% \mathrm{~m} / \% \mathrm{~d} \% \mathrm{H}: \% \mathrm{M}$
12) $\% \mathrm{Y} / \% \mathrm{~m} / \% \mathrm{~d}$
13) $\% \mathrm{H}: \% \mathrm{M}: \% \mathrm{~S}$
14) $\% \mathrm{H}: \% \mathrm{M}: \% \mathrm{~S} . \% \mathrm{f}$
15) $\%$ Y.\%m.\%d \%H:\%M:\%S.\%f
16) $\%$ Y.\%m.\%d \%H:\%M:\%S
17) $\%$ Y.\%m.\%d \%H:\%M
18) $\%$ Y.\%m.\%d
19) $\% \mathrm{Y} \% \mathrm{~m} \% \mathrm{~d} \% \mathrm{H} \% \mathrm{M} \% \mathrm{SED}$

Format timestamplain dapat pula ditambahkan pada daftar "supported formats"yang terletak dalam file time_util.py. Time Manager saat ini tidak mendukung format yang akan menempatkan menit atau detik sebelum jam.Time Managertelah diuji dengan berbagai format data seperti PostgreSQL, Spatialite, delimited text layer, dan shapefile (.shp).

Tampilan animasi dapat diatur dengan mengakses tombol pengaturan (settings) yang terdapat dalam dock widget. Pengaturan terbagi menjadi dua bagian, yaitu bagian Layers dan Animation options (Gambar 3). Bagian layersdigunakan untuk menambahkan data dan menentukan cara animasinya, sementara itu bagian animation options digunakan untuk mengatur beberapa hal umum dalam animasi seperti durasi setiap frame, loop animation, menampilkan penunjuk waktu, dan menjalankan animasi dengan timeline terbalik. 


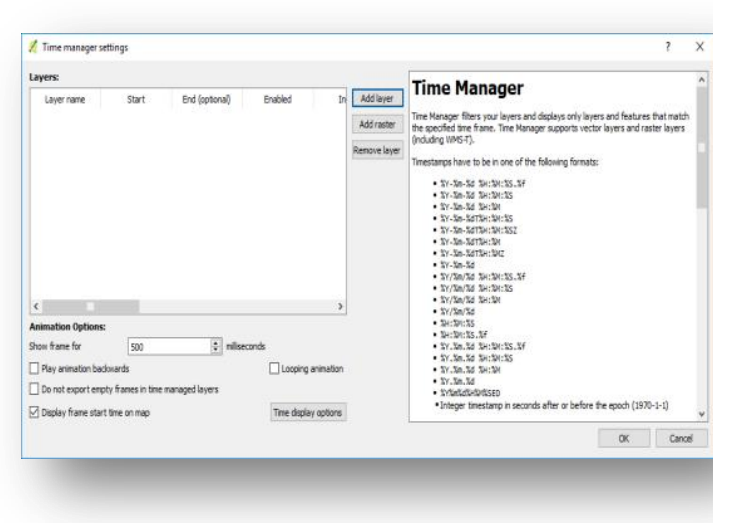

Gambar 3 Pengaturan animasi

Penambahan data dilakukan dengan menggunakan tombol Add layer, yang mana pengguna dapat mengatur data apa yang akan dibuat animasi dan kolom mana yang menyimpan data timestamp (Gambar 4). Data timestamp dibutuhkan untuk menentukan Start time dan End time, meskipun untuk yang kedua opsional.Terdapat pula pilihan untuk melakukan interpolasi data, yang dalam ranah animasi umum disebut dengan istilah tweening.Offset digunakan untuk memberikan jeda jika ingin memberikan efek pemunculan dua atau lebih data dalam satu animasi.



Gambar 4 Pengaturan data untuk animasi

Hasil animasi dapat disimpan dalam bentuk picture frame dan video, namun dukungan video hanya tersedia untuk sistem operasi Linux dan iOS. Pada sistem operasi Windows, pilihan penyimpanan hanya tersedia picture frame saja.

\section{c. Pengaturan Speed dan Step Size} Penyampaian animasi yang efektif dilakukan melalui pengujian tampilan animasi yang dihasilkan.Dua hal yang mempengaruhi tampilan animasi ialah kecepatan pergantian antar frame (speed) dan jeda waktu nyata antar frame (step size). Waktu yang terlalu cepat untuk menampilkan antar frameakan semakin menyedot perhatian pembaca sehingga dimungkinkan terdapat informasi yang tidak tersampaikan. Di sisi lain apabila waktu antar frame terlalu lambat, maka efek perubahan yang dihasilkan akan berkurang.

Jeda waktu nyata dijalankan menurut hitungan waktu sebenarnya.Dalam hal ini diperlukan generalisasi yang cukup sehingga dapat dilihat agregat data, dengan tetap memperhatikan kedetailan waktu yang telah tersedia dalam data. Kedua hal inilah yang akan dieksplorasi dalam rangka menampilkan data kejadian gempa bumi.

\section{Hasil dan Pembahasan}

Berdasarkan data kejadian gempabumi yang diperoleh, data paling awal tertanggal 02-01-2015 pukul 20:11:08, sementara data terakhir ialah 23-04-2018 pukul 08:13:58. Rentang waktu antara keduanya ialah 40 bulan.Gambar 1.5 menunjukkan jumlah gempabumi per bulan pada setiap tahun. Data tahun 2018 menunjukkan lonjakan jumlah gempabumi yang cukup signifikan dibandingkan dengan ketiga tahun yang lain. Analisis lebih lanjut menunjukkan bahwa rata-rata terdapat 18 kejadian gempabumi per bulan, yang mana memiliki magnitudo lebih dari 5. Data rata-rata ini dapat digunakan sebagai acuan untuk menentukan step size yang tepat.

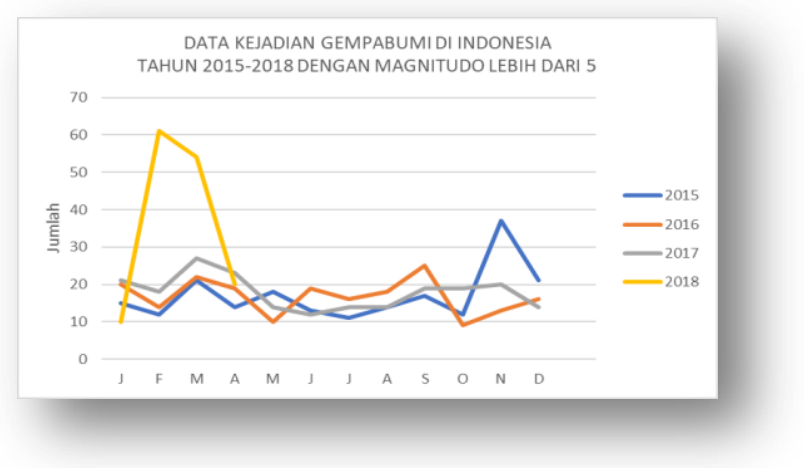

Gambar 5 Jumlah kejadian gempabumi

Satuan step size yang disediakan oleh Time Managersangat lengkap, mulai dari 
hitungan mikrodetik hingga tahun. Berdasarkan nilai rata-rata kejadian gempabumi per bulan yang telah diperoleh, akan dicobakan tiga variasi step size, yaitu setiap 2 minggu, setiap 1 bulan, dan setiap 2 bulan. Selain melakukan variasi pada step size, dilakukan variasi pula pada speed, yang mana akan dicobakan pada 500 milidetik, 750 milidetik, dan 1.000 milidetik.

Visualisasi data gempabumi ditujukan untuk memperlihatkan data historis kejadian, sehingga data pada frame yang telah berjalan diharapkan tetap pada posisinya. Pengaturan terhadap hal ini dapat dilakukan pada End time yang diubah menjadi No end time - accumulate features. Pada posisi default, end time terpilih pada posisi Same as start yang berarti frame yang telah berjalan tidak akan ditampilkan pada frame berikutnya.

Pengaturan step size secara langsung akan mempengaruhi jumlah frame yang dihasilkan dalam animasi. Seperti terlihat pada Tabel 1.1, semakin dekat jarak step size maka jumlah frameakan semakin banyak. Perbedaan speed terbukti tidak berpengaruh terhadap jumlah frame, karena pada ketiga speed yang dicobakan selalu menghasilkan jumlah frame yang sama. Efek multiplikasi jumlah frame juga terlihat pada step size yang berbeda, yang tentunya memiliki hubungan terbalik.

Tabel 1 Hubungan step size dan speed dengan jumlah frame yang dihasilkan

\begin{tabular}{|c|l|c|c|c|}
\hline \multicolumn{2}{|c|}{} & \multicolumn{3}{c|}{ Step size } \\
\cline { 3 - 5 } \multicolumn{2}{|c|}{} & 2 minggu & 1 bulan & $\begin{array}{l}2 \\
\text { bulan }\end{array}$ \\
\hline \multirow{2}{*}{$\approx$} & $500 \mathrm{md}$ & 87 & 40 & 20 \\
\cline { 2 - 5 } & $750 \mathrm{md}$ & 87 & 40 & 20 \\
\hline \multirow{2}{*}{$-1.000 \mathrm{md}$} & 87 & 40 & 20 \\
\hline
\end{tabular}

Secara visual aspek animasi yang nyaman untuk dilihat, dihasilkan oleh pengaturan step size 2 minggu. Penambahan data gempabumi terlihat lebih halus, jika dibandingkan dengan kedua step size lainnya. Nilai rata-rata kejadian gempabumi sebanyak 18 kejadian per bulan. Jika jumlah tersebut disajikan dalam satu frame yang cukup luas, maka perubahan yang ditampilkan akan terkesan terlalu cepat. Pada pengaturan step size 2 minggu, setiap frame rata-rata akan mengalami pertambahan 9 kejadian gempa. Pertambahan jumlah titik gempa yang relatif lebih kecil ini akan menghasilkan efek animasi yang lebih halus.

Pengamatan efek speed terhadap hasil animasi hanya dapat dilakukan pada media digital.Secara umum, speed 750 milidetik memberikan perimbangan kecepatan kepada pembaca peta animasi, yang mana tidak terlalu cepat juga tidak terlalu lambat. Pada proses pembuatan peta animasi yang lain, pengaturan speed dapat dilakukan dengan caratrial and error untuk menentukan kecepatan yang tepat. Hal ini disebabkan karena dalam penampilan animasi jenis data yang akan ditampilkan juga berpengaruh, sesuai dengan prinsip perubahan yang cepat atau yang lambat.

Eksplorasi visualisasi lebih lanjut dapat dilakukan dengan menambahkan efek offset atau menggunakan teknik interpolasi. Efek offset yang dikombinasikan dengan penambahan layer data dapat membuat data geospasial pada peta animasi memiliki kesan meninggalkan jejak. Jika animasi dibuat tanpa efek apapun, maka data geospasial akan terkesan menumpuk data. Hal ini mungkin kurang menarik bagi pembaca. Gambar 1.6 menujukkan contoh penambahan efek offset dan penambahan layer pada peta animasi. Titik warna kuning menunjukkan titik kejadian gempabumi pada waktu yang tertera di kanan bawah, sementara titik-titik putih merupakan kejadian gempabumi yang telah berlangsung.

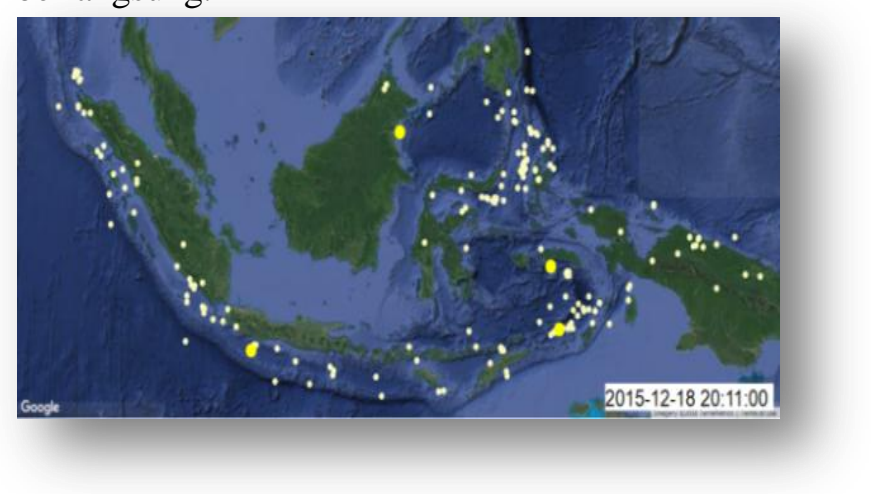




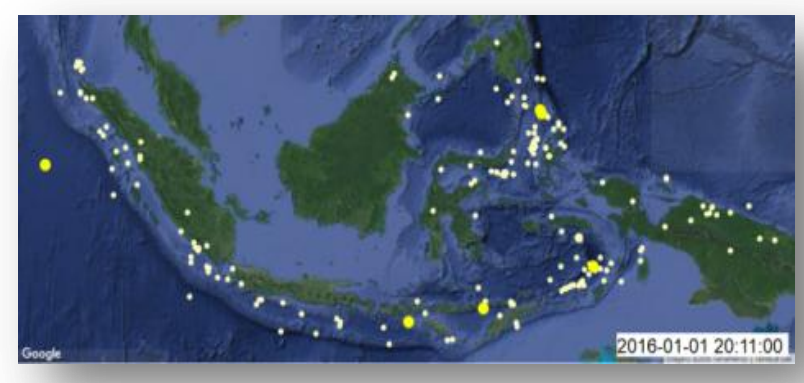

Gambar .6 Peta animasi a) frame ke-25 dan b) ke-26, yang dibuat dengan menggunakan efek offset dan penambahan layer data.

Teknik tweening yang difasilitasi oleh plugin Time Managermelalui interpolasi memiliki keterbatasan hanya dapat digunakan untuk data dengan geometri titik dan dataset berukuran besar. Pada dasarnya untuk melakukan interpolasi tersebut dibutuhkan minimal dua data waktu, yaitu awal dan akhir. Algoritma interpolasi akan menentukan pergerakan dari titik awal menuju titik akhir berdasarkan posisi geometrisnya. Namun demikian teknik ini tidak tepat digunakan untuk data gempabumi karena tidak diperlukan interpolasi pergerakan.

\section{Kesimpulan}

Pengaturan step size dapat ditentukan dengan memperhatikan nilai rata-rata jumlah kejadian data geospasial dalam suatu waktu. Jumlah yang ideal untuk pemunculan data dalam satu frame memang dipengaruhi oleh data geospasial itu sendiri. Dari percobaan yang telah dilakukan pada data kejadian gempabumi, menunjukkan bahwa jumlah yang relatif lebih sedikit akan memberikan efek animasi yang lebih nyaman bagi pembaca peta. Sementara itu pengaturan speed, dapat dilakukan dengan caratrial and error untuk menentukan efek perubahan yang seimbang.

Plugin Time Managermampu menyajikan peta animasi dengan sangat baik. Fitur yang disediakan pun cukup menarik untuk perangkat lunak open source.Pengguna dapat membuat peta animasi sederhana, selama data yang digunakan memiliki timestamp. Adanya fasilitas efek offset, interpolasi, penanganan data raster dan layering, akan memberikan keleluasaan bagi pembuat peta animasi.

Beberapa keterbatasan yang dijumpai pada plugin Time Managerdiantaranya ialah: a) jika format timestamp tidak sesuai dengan format yang ada maka diperlukan modifikasi yang tentunya tidak mudah bagi orang yang awam, dan b) tidak adanya opsi untuk ekspor peta animasi dalam format video bagi pengguna dengan sistem operasi Windows.

\section{Daftar Pustaka}

[1] Kraak, M. dan Ormeling, F., Cartography: Visualization of Spatial Data. Essex, Pearson Education Limited, 2010.

[2] Bertin, J.,Semiology of Graphics: Diagrams, networks, maps, Redlands, California, Esri Press, 2011.

[3] Harrower, M. and Fabrikant, S., The Role of Map Animation for Geographic Visualization, in Geographic Visualization: Concepts, Tools and Applications, West Sussex, John Wiley \& Sons Ltd, 2008, pp. 4965

[4] Kraak, M., Edsall, R.dan MacEachren, A., "Cartographic Animation and Legends for Temporal Maps Exploration and or Interaction," in 18th ICA International cartographic conference, Stockholm, 1997

[5] Kraak, M., Cartography and the Use of Animation, in Multimedia Cartography, New York, SpringerVerlag Berlin Heidelberg, 1999, pp. 173-180.

[6] Graser, A., Free and Open Source GIS Ramblings, 2011. [Daring]. URL: https://anitagraser.com/projects/timemanager/. [Diakses 2018].

[7] Oskin, B., What Is Plate Tectonics?, Livescience, 19 December 2017. [Daring]. URL: https://www.livescience.com/37706what-is-plate-tectonics.html. [Diakses 30 April 2018] 